which the conviction of the offender was procured by the exertions of the administrators of the commune.

Such were the proposals contained in the programme relative to this branch of the general subject; and they were submitted to a sub-committee, presided over by Professor Mittermayer, of Heidelberg, the most profound jurisconsult of Germany, who reported the result of the discussion to the general meeting of the Congress.

After a preliminary observation, he stated that the section proposed to the Congress to adopt the propositions as they had been drawn up. He then proceeded: We suppose that the Legislature will understand the great difficulties of framing their enactments with reference to the measures to be taken and the penalties to be imposed in the case of their violation. The words fraud and adulteration are very vague, and leave too much to interpretation. It is difficult to mark the limits of lawful speculation, and to define punishable actions. Amongst those frauds, there are mixtures of aliments with other substances solely with the view of augmenting the quantity of the article sold. In other cases, the substances which are added, without being injurious in themselves, do not possess sufficient nutritive properties; while in others, the substances added are more or less injurious to health. The Legislature must, therefore, define several classes of prohibitions and offences in reference to these frauds, and graduate the punishment according to the extent of the culpability. Difficulties occur in respect to the discovery and proof of these frauds. Many of these offences are not prosecuted. The persons who have suffered from them do not like to bring their complaints before the courts of justice or before the police, particularly in cases of slight importance. Again, the purchasers of some articles are well aware of the practice of the dealers therein to make mixtures (as in the case of bread, milk, and butter), but are indifferent to the practice, and thus the frauds remain unpunished. Then the measures taken for prevention are often vexations and restrictive, leaving too much to the action of inferior agents, and this circumstance is another cause why such measures often fail. The programme has very well laid down, in articles No. 1 to No. 6, the important measures and regulations which the Legislature might require to be carried into execution, and the section approved of them entirely. But another difficulty attaches in regard to the verification of these frauds. For this purpose, recourse must be had to persons of skill for information as to the nature and influence of certain combina tions, and as to the means of discovering adulterations. But when we seek their advice, and compare the opinions and doctrines hitherto entertained on these subjects with those which the general progress of science inculcates, we at once perceive the necessity of referring all tests and instructions as to the means of discovering adulterations to the revision of men who have applied themselves profoundly to this particular branch of science. The report lately published by the committee of the English Parliament on the Adulterations of Food contains very important materials, and proves that there is a great diversity in the opinions of the medical men examined as witnesses as to the influence of certain combinations; as, for example, those employed by bakers to colour bread. The section entirely approved of the measures proposed in the programme for the repression of these frands and adulterations.

The learned Professor then adverted to a proposition which had been made to the section, but not adopted, with reference to the publicity of all prosecutions, which need not be further noticed; and concluded by proposing to the Congress to adopt all the propositions set forth in the programme and detailed above. This was done without any opposition.

I am, Sir, your obedient servant,

October, 1856.

W. G. LUMLEY.

* * The above letter exhibits the importance attached to the subject by our Continental neighbours. The suggestions contained in it are well worthy the consideration of those who may undertake the duty, during the next session of Parliament, of bringing in a Bill for the repression of adulteration. - ED. L.

\section{THE ROYAL MEDICAL BENEVOLENT COLLEGE.}

To the Editor of THE LANCET.

SIR,-I have been in hope that the several communications which have lately been inserted in THE LANCET, respecting the management of the Royal Medical Benevolent College, would have drawn from your editorial pen some remarks that would have awakened the attention of the Council to the growing dissatisfaction amongst those necessarily interested. Whatever may be defective in the internal or domestic arrangements, I view as paramount the meagre and totally insufficient number of instructors for a school of such magnitude. On this point I lately addressed a few observations to THE LANCET, which were followed up by your correspondent, "A Life Governor."

Let me give you the example of a private school, at which I have placed a younger boy. He is one of thirty-six pupils, and they have the benefit of a resident French and German master, both natives; an English teacher; the classics and some collateral branches being conducted by the proprietor himself.

I believe, with your correspondent, that as yet the teaohing of the modern languages at the Medical College is a mere farce; in fact, I look upon it as next to an absurdity for either French or German to be taught by others than natives of their own country; and how many of such must there be in London, whose services could be obtained at almost a nominal salary, and what the proportional expense of their board in so large an establishment?

The subject must be looked to, or the prosperity of the Royal Medical Benevolent College will wither under the breath of a disappointed public.

October, 1856.

I am, Sir, yours obediently,

\section{To tha Editor of The Lancet.}

Str,-In reference to the letters which have lately appeared in Tre Lancer respecting the Royal Medical Benevolent College, I would, before it is too late, earnestly appeal to the good feelings of the Council, to no longer withhold the publication of detailed particulars of all receipts and disbursements, together with the working expenses of office and College, specifying every salary. I should not have intruded myself on your notice did not I believe such an explanation to be imperatively called for; indeed the future well-being of the College is at stake, as silence and secresy in the pecuniary affairs of so large an undertaking only tends (however unjustly) to excite distrust as to judicious application, and thus engender a want of confidence in the general management.

We have all, I feel convinced, the same end in view, and are actuated by the same beneficent motives, of assisting the widows, the orphans, and the decayed members of our common profession, as well as securing a really good education for our boys, at such a cost as may meet the circumstances of the least favoured amongst us.

$\Upsilon$ do then most sincerely hope that the next week's LANCET may contain a satisfactory report from the Council, and I trust that, so far from paying the indomitable Mr. Propert the iil compliment of withholding our subscriptions and assistance, we shall, one and all, vie with each other in the support of the real interests of our sons' alma mater.

October, 1856. I am, Sir, your obedient servant,

\section{THE CONTROVERSY BETWEEN DR. LEE AND} DR. SNOW BECK.

To the Editor of THE LANCET.

SIR,-T shall esteem it a favour if you will insert the following copy of a correspondence betwixt Mr. West and myself in an early number of your journal. The facts there stated so clearly explain the question at issue, that any comment of mine would be altogether superfluous. I am, Sir, yours faithfully,

\section{Savile-row, October, 1856 Robert LeE}

4, Savile-row, October 11th, 1856

Mr Dear Sir, - In The LaNcet of the 19th July, 1S56, the following statement was made by Dr. Beck, in a note appended to one of his communications to that journal:-

"The following anecdote may perhaps tend further to elucidate this point:- The artist usually employed by Dr. having been seized with paralysis, he applied to the artist who made the drawings I required. At this time the artist was engaged in making some drawings for me, and during one of the periodical visits of inspection I made to ascertain, in the progress of the drawing, that the dissections were accurately represented, Dr. - 's carriage drove to the door. The artist appeared much flurried at this, and hurriedly adjourned to the next room to receive his other visitor, leaving me to compare the drawings with my dissection. It was in the month of May, the weather fine, and the doors of the two rooms, which were 
open, immediately adjoining; the rooms, moreover, were very small, and the partition thin. Thus placed, I was obliged to hear the following dialogue:-Author." Well, Mr. - , how are you getting on? Ab! that will do. Now you must put in the ganglia. Let me see; you must put in a ganglion there.' A short time elapsed, when the artist said, 'But I don't see any ganglia.' 'Never mind,' replied the author; 'they are there, but you cannot see them; you must put a ganglion here -a little larger-there, that will do. Now, yon must put another here-very well, that will do.' And so on. And when the anthor had gone, the surface of the heart was represented. studded over with numerous ganglia and gangliform enlargements. To my remonstrance of 'How could you do this?' the artist replied, "What can I do? I am obliged to do as I am directed." "

You being the "artist" here referred to, and it being generally believed that I am the "author" therein noticed, you will oblige me much by stating whether the previous report of a conversation said to have taken place at your house be correct, or only imaginary.

I im, my dear Sir, very faithfully yours,

To Edgar West, Esq., 6, Trure-strect, Haverstock-hill.

ROBERT LEE.

P.S. - Your recent absence from London, and my not being able till now to obtain your correct address, explains why you have not heard from me sooner in reference to the present inquiry.

R. L.

Trure-street, October 13th, 1856.

MY DEAR DR., - You wish to know who I think are meant by the "Dr." and "artist," named in what is called an "anecdote" published in TIIE LANCET by Dr. Beck. Undoubtedly you and myself are the two unfortunates. I remember the circumstances perfectly, but must give a very different version of it, and one not at all to the credit of Dr. Beck. Now, if I understand the word " anecdote," it means a truthful account of some past event; but I am sorry to say for Dr. Beck's sake as a gentleman, that what he calls "anecdote" is a shameful tissue of falsehood throughout. In the first place, he was not at my house by accident, as he wishes to make it appear, when you arrived, but came purposely to examine your dissection, and not, as he states, on his own business, and was actually sitting at the table in the front room, with your preparation before him, when your carriage drove to the door. He jumped up, and ran into the back room to hide, where, by his own confession, (which I am much surprised that he should have the temerity to publish,) he became that honourable character, an Eavesdropper. Actions are much better remembered than words, after a lapse of so many years; but I am certain (notwithstanding Dr. Beck's very fertile memory of every word which he says passed between the "Dr." and "artist," and which he owns he was treasuring up with his ear glued to the key-hole of the folding-doors) that his statement of the conversation, which then took place, is quite as TRUE as the rest of his so-called "anecdote."

I am only surprised that a man of Dr. Beck's station in life should not, before he published such a made-up tale, have been more careful of his own character, which, after this correct statement of facts, must appear to every unprejudiced mind far more tarnished than the one he wishes to injure.

To Dr. Lee. I am, dear Dr., your obedient servant,

** As this controversy has entirely exceeded the bounds of legitimate discussion, we must, in the most positive manner, decline to continue it. Dr. Snow Beck will, we think, ever deeply regret having published the statement which has elicited the letter of Mr. Edgar West.-ED. L.

\section{DR. BROOKES' CASE OF INGUINAT ANEURISM. \\ To the Editor of THE LANCET.}

SIR,- - I have neither time nor inclination to answer the letter of Mr. Fred. H. Morris, in your last number.

My external iliac case was seen by at least twenty surgeons, and the operation witnessed by nearly a like number. I was also kindly assisted by Dr. Eves, a well-known hospital surgeon of thirty years' standing. Not one of these gentlemen doubted the nature of the case or the ligature of the artery.

If I may give a word of ad vice to your correspondent, it is, to at once attend a course of lectures on operative surgery, and read Mr. Hodgson's excellent work on the Arteries, before he again attempts to write on a subject he evidently knows little about.

I am, Sir, your obedient servant,

Cheltenham, October, $1856 . \quad$ Wm. Phinpot Brookes.

P.S. - I enclose the ligature for your inspection.

\section{THE CITY GAS-WORKS.}

"The legitimate object of Medicine is the preservation of health, the restoration of health, the prolongation of life, and the alleviation of suf-
foring when death cannot be averted."

\section{To the Editor of THE LANCET.}

Srr, - In the hope that through your influential Journal this communication, relating to the City Gas-works nuisance, may reach the proper quarter, $I$ address you. It is surprising that a mode of disposing of the sources of the foul emanations so simple and so perfect as the following, has not occurred to the gas-manufacturers:-Let a well be sunk, 100 feet deep and 6 feet diameter, on the premises; into this well let the dry lime used in purifying the gas be thrown, and upon it a portion of vegetable chareoal. Beside the first well, let a second be commenced, a portion of the earth of which, sufficient to corer the mass at the bottom of the first well, being thrown upon it; so that the sinking of the second well and the filling-up of the first might go on pari passu. In this way, by burying the sources of the nuisance deeply in the earth, no noxious gases could escape to pollute the surrounding atmosphere.

October, 1856 .

J. PIDDdCK.

\section{TIE DEATH FROM CHLOROFORM AT S'T. THOMAS'S HOSPITAL.}

THE patient, John Gibbing, aged thirty-six, sailor, a stout, middle-sized man, was to be operated on for necrosis of the phalanges of one of his fingers. He was very anxions to have the operation performed under chloroform, which was, there being no obvious contra-indication, administered. One drachm of chloroform was poured upon a sponge folded up in lint, and this was held over his mouth and nose, so as to allow of free inhalation of the atmosphere together with the vapour. After about twenty inspirations he began to spit into the lint, and retch. The chloroform was removed, and he was shortlyperhaps scarcely a minute-after seized with convulsions, necessitating his being held by three or four men. This having lasted some thirty seconds, his face became blanched, and he gasped for breath. He was placed in a horizontal position, the tongue held forward by forceps, and artificial respiration commenced; air could be heard entering the lung at each inspiration. Under this treatment, together with the application of ammonia to the nostrils, he rallied for a few seconds, so as to be able to breathe naturally. Again he ceased to breathe. Artificial respiration was recommenced; the galvanic current was passed from the nape of the neck to the region of the heart; oxygen was injected into the chest; but in vain. His heart acted no more, and he was dead. The remedial measures mentioned were continued for nearly half an hour after he had given any signs of life.

Post-mortem Appearance.-Fatty degeneration of the heart in an early stage. Fatty liver. Slight anæmia of the brain. No valvular disease of the heart.

The death occurred on the 14th instant. On the Saturday previous he went to the hospital as an out-patient, and had his finger incised, to relieve the great tension of the part, and a considerable quantity of blood was lost. He had suffered from delirium tremens three times, the last time being three weeks before applying to the hospital. He had been in the habit of drinking a pint and a half of rum daily for nine years, according to the account of parties who had known him for a length of time.

Sin Henry Hortand in America.-It is stated in a late Canadian paper that Sir Henry Holland has arrived in the Canadas, for the purpose of ascertaining whether the climate is in every way favourable to encourage a visit from her Majesty next summer to that portion of the British dominions. It has long been rumoured that the Queen is desirous of taking a trip across the Atlantic to visit her Canadian subjects. Sir Henry Holland's journey to that country we do not think has any. thing to do with it. 